\title{
ACTIVITY OF ANTIOXIDANT SYSTEM AND GROWTH INTENSITY IN COMMON CARP AFTER FEEDING DIET WITH DIFFERENT CONTENTS OF COPPER AND ZINC
}

\author{
N. E. Yanovych ${ }^{1}$, Y. F. Rivis ${ }^{2}$ \\ yandeni77@gmail.com
}

${ }^{1}$ Lviv National University of Veterinary Medicine and Biotechnologies

named after S. Z. Gzhytsky,

50 Pekarska str., Lviv 79010, Ukraine

${ }^{2}$ Institute of Agriculture of Carpathian Region NAAS,

5 Grushevskogo str., Obroshino, Lviv Oblast, 81115, Ukraine

Copper and Zinc are essential for fishes elements with wide spectrum of biological activity, however their simultaneous influence on the activity of antioxidant system and carp growth in physiological and excessive concentrations demands further investigations. Actuality of following experiments is determined, inter alia, by species differences of susceptibility of fishes to increased content of trace elements in diet, organic and tissue peculiarities of their distribution in organism.

This paper presents that at Copper concentration in mixed fodder equated to 1 MPL (maximum permitted level) it accumulates in the gills of carp in greater measure than in the liver and skeletal muscles. At the same time, Zinc accumulates equally in the gills, liver and skeletal muscles. At 2 MPLs in mixed fodder, Copper accumulates equally in all abovementioned tissues of carp, while Zinc accumulates preferably in the gills and liver, than in the skeletal muscles. At 1 MPL of Copper and Zinc in mixed fodder, activity of main antioxidant enzymes in the carp gills, liver and skeletal muscles is increasing against the decreasing of lipid peroxidation products level. At 2 MPL of Copper and Zinc in mixed fodder, level of lipid peroxidation products in the gills, liver and skeletal muscles of carp is conversely increasing. During the experiment (45 days), carps of control group increased their live weight 1.65 times, and carps of the $1^{\text {st }}$ and $2^{\text {nd }}$ experimental groups -1.94 and 1.82 times, respectively.

Keywords: ENZYMES, LIPID PEROXIDATION PRODUCTS, COPPER, ZINC, GILLS, LIVER, SKELETAL MUSCLES, CARP

\section{АКТИВНІСТЬ АНТИОКСИДАНТНОЇ СИСТЕМИ ТА РІСТ КОРОПІВ ПРИ ЗГОДОВУВАННІ КОМБІКОРМУ 3 РІЗНИМ ВМІСТОМ МІДІ І ЦИНКУ}

\author{
Н. С. Янович ${ }^{1}$, Й. Ф. Рівіс ${ }^{2}$ \\ yandeni77@gmail.com
}

\begin{abstract}
${ }^{1}$ Львівський національний університет ветеринарної медицини
та біотехнологій ім. С. З. Гжицького,

вул. Пекарська, 50, м. Львів, 79010, Україна

${ }^{2}$ Інститут сільського господарства Карпатського регіону НААН,

вул. Грушевського, 5, с. Оброшино, Львівська область, 81115, Україна
\end{abstract}

Мідь та Цинк належать до життєво важливих для риб елементів з широким спектром біологічної дії, проте їхній одночасний вплив у фізіологічних та понаднормових концентраціях на систему антиоксидантного захисту та ріст коропа потребує подальшого вивчення. Актуальність таких досліджень продиктована зокрема видовими відмінностями чутливості риб до підвищеного вмісту мікроелементів у кормі та органно-тканинними особливостями ӥхнього розподілу в організмі.

При виконанні иієї роботи було встановлено, щьо за однієї граничної концентрації у комбікормі Мідь у коропів нагромаджується в зябрах більшою мірою, ніж у печінщі та скелетних м'язах, а Цинкоднаковою мірою у зябрах, печінці та скелетних м'язах. За двох гранично допустимих конщентрацій у комбікормі Мідь нагромаджується у всіх тканинах організму коропів однаково, а Цинк - більшою мірою у зябрах і печінці, ніж у скелетних м'язах. За однієї гранично допустимої концентрації Міді та Цинку 
в комбікормі у зябрах, печіниі та скелетних м'язах коропів підвищується активність основних ензимів антиоксидантного захисту та знижується рівень продуктів перекисного окиснення ліпідів. За двох гранично допустимих концентрацій Міді та Цинку в комбікормі у зябрах, печінці та скелетних м'язах коропів, навпаки, зростає вміст продуктів перекисного окиснення ліпідів. За період досліду (45 днів) коропи контрольної групи збільшили свою живу масу в 1,65 разу, а коропи I та II дослідних груп-відповідно, в 1,94 i 1,82 paзy.

Ключові слова: ЕНЗИМИ, ПРОДУКТИ ПЕРЕКИСНОГО ОКИСНЕННЯ ЛІПІДІВ, МІДЬ, ЦИНК, ЗЯБРА, ПЕЧІНКА, СКЕЛЕТНІ М'ЯЗИ, КОРОПИ

\title{
АКТИВНОСТЬ АНТИОКСИДАНТНОЙ СИСТЕМЫ И РОСТ КАРПОВ ПРИ СКАРМЛИВАНИИ КОМБИКОРМА С РАЗНЫМ СОДЕРЖАНИЕМ МЕДИ И ЦИНКА
}

\author{
Н. Е. Янович ${ }^{1}$, И. Ф. Ривис ${ }^{2}$ \\ yandeni77@gmail.com
}

${ }^{1}$ Львовский национальный университет ветеринарной медицины

и биотехнологий им. С. З. Гжицкого,

ул. Пекарская, 50, г. Львов, 79010, Украина

${ }^{2}$ Институт сельского хозяйства Карпатского региона НААН,

ул. Грушевского, 5, с. Оброшино, Львовская область, 81115, Украина

Медь и Цинк относятся к числу жсизненно важнных для рыб элементов с иироким спектром биологического действия, однако их одновременное влияние в физиологических и сверхнормативных кониентрациях на систему антиоксидантной защиты и рост карпа требует дальнейшего изучения. Актуальность таких исследований продиктована в том числе видовыми различиями чувствительности рыб к повышенному содержанию микроэлементов в корме и органно-тканевыми особенностями их распределения в организме.

При выполнении данной работь было установлено, что при одной предельно допустимой концентрации в комбикорме Медь накапливается в мышизах в большей степени, чем в печени и скелетных мышиах, а Цинк - в одинаковой степени в жабрах, печени и скелетных мышиах. При двух предельно допустимых концентрациях в комбикорме Медь накапливается в одинаковой степени во всех тканях карпа, а Цинк - в большей степени в жабрах и печени, чем в скелетных мышиах. При одной предельно допустимой кониентрации Меди и Цинка в комбикорме в жабрах, печени и скелетных мышцах карпа повышается активность основных ферментов антиоксидантной системь и понижается уровень продуктов перекисного окисления липидов. При двух предельно допустимых концентрациях Меди и Цинка в комбикорме в жабрах, печени и скелетных мышиах карпа, наоборот, увеличивается содержание продуктов перекисного окисления липидов. На протяжении исследований (45 дней) жсвая масса карпов контрольной группь увеличилась в 1,65 раза, а карпов I и II экспериментальньх групп - соответственно, в 1,94 и 1,82 раза.

КлючевЫе слова: ФЕРМЕНТЫ, ПРОДУКТЫ ПЕРЕКИСНОГО ОКИСЛЕНИЯ ЛИПИДОВ, МЕДЬ, ЦИНК, ЖАБРЫ, ПЕЧЕНЬ, СКЕЛЕТНЫЕ МЫШЦЫ, КАРПЫ

As a result of industrial and agricultural production, fishponds can accumulate increased concentrations of heavy metals [1, 2], those, depending on their properties, valence and content, can affect metabolic processes in the freshwater fishes [3-5], mainly as a constituents of numerous enzymes [6]. For instance, Zinc is a part of the antioxidant enzyme superoxide dismutase; also, it regulates the activity of $\Delta^{3}-, \Delta^{4}-, \Delta^{5}$ - and $\Delta^{6}$ - desaturases [6-8]. Copper influences the activity of antioxidant enzymes superoxide dismutase and catalase; besides, it affects the ac- tivity of $\Delta^{9}$-desaturase [9]. The desaturases are involved in fatty acids metabolism in fishes. Moreover, heavy metals, firstly divalent (Zinc, Copper, Lead, Cadmium etc.) are able to form salts (soaps) with fatty acids [10]. Thus, Copper and Zinc while involving in regulation of the antioxidant enzymes activity and fatty acids metabolism in tissues of freshwater fishes, can indirectly influence on fish growth and biological value of fish meat.

The aim of our experiment was to research of the activity of main antioxidant enzymes in tis- 
sues of carp and growth intensity under different concentration of Copper and Zinc in mixed fodder.

\section{Materials and methods}

The experiment was conducted on three groups (4 fishes in each group) of two year old common carp (Cyprinus carpio L.) with average live weight $332 \mathrm{~g}$. For 45 days carps were kept in pongs $0.04 \mathrm{sq}$ hectares each.

Carps of control group were fed standard granulated mixed fodder (K 111-3/4) without inclusion of Copper and Zinc. Carps of the $1^{\text {st }}$ and $2^{\text {nd }}$ experimental groups were fed the same fodder with addition of sulfates of Copper and Zinc.

Concentration of Copper and Zinc in the mixed fodder for the $1^{\text {st }}$ experimental group achieved 1 MPL ( 8 and $100 \mathrm{mg} / \mathrm{kg}$ correspondingly), while for the $2^{\text {nd }}$ experimental group it achieved 2 MPL (16 and $200 \mathrm{mg} / \mathrm{kg}$ correspondingly). Sulfates of Copper and Zinc were added to the mixed fodder on its granulation. Standard mixed fodder and mixed fodder with heavy metals addition were fed daily to the carps in dosage $6 \%$ of their live weight at 8 am.

In the end of experiment the carps were weighted, after that three carps from each group were slaughtered and samples of the gills, liver and skeletal muscles were taken for laboratory research. In mentioned tissues samples the activity of superoxide dismutase, glutathione peroxidase and catalase was estimated [11-13], as well as concentration of Copper, Zinc [14], primary and secondary lipid peroxidation products [15-17].

Results of investigations were processed statistically. Average magnitude (M), average error $( \pm \mathrm{m})$ and probability of differences between two average magnitudes $(\mathrm{P})$ were calculated. Difference between two average magnitudes was considered probable at $\mathrm{P}<0.05$. For calculations the programs Origin 6.0, Excel (Microsoft, USA) were used.

\section{Results and discussion}

It was revealed, that at Copper concentration in mixed fodder equated to 1 MPL in comparison to its natural content, it accumulates in the gills in greater extent $(\mathrm{P}<0.01)$ than in the liver and skeletal muscles $(\mathrm{P}<0.05)$. Zinc at concentration in the mixed fodder equated to $1 \mathrm{MPL}$ accumulates equally in the gills, liver and skeletal muscles $(\mathrm{P}<0.05)$. At $2 \mathrm{MPL}$ in the mixed fodder, Copper accumulates in all investigated tissues of carp in the same extent $(\mathrm{P}<0.05)$, while Zinc accumulates foremost in the gills and liver $(\mathrm{P}<0.01)$, and secondarily - in the skeletal muscles $(\mathrm{P}<0.05)$ (Table 1).

Increasing of Copper and Zinc concentration in carp tissues led to changes of the activity

\section{Concentration of Zinc and Copper in carp tissues} under their different contents in mixed fodder, $\mathrm{mg} / \mathrm{kg}$ of living weight $(\mathrm{M} \pm \mathrm{m}, \mathrm{n}=4)$

\begin{tabular}{|c|c|c|}
\hline Control group & $\begin{array}{c}\text { The } 1^{\text {st }} \text { Experimental group } \\
\text { (1 MPL of Zinc and Copper in mixed fodder })\end{array}$ & $\begin{array}{c}\text { The } 2^{\text {nd }} \text { Experimental group } \\
(2 \mathrm{MPL} \text { of Zinc and Copper in mixed fodder })\end{array}$ \\
\hline \multicolumn{4}{|c|}{ Concentration of Zinc in the gills } \\
\hline $233.97 \pm 6.011$ & $271.10 \pm 5.523^{*}$ & $279.73 \pm 5.494^{* *}$ \\
\hline \multicolumn{4}{|c|}{ Concentration of Zinc in the liver } \\
\hline $185.57 \pm 4.542$ & $211.97 \pm 5.171^{*}$ & $220.97 \pm 4.161^{* *}$ \\
\hline \multicolumn{3}{|c|}{ Concentration of Zinc in the skeletal muscles } \\
\hline $13.50 \pm 0.550$ & $15.80 \pm 0.522^{*}$ & $16.23 \pm 0.502^{*}$ \\
\hline \multicolumn{3}{|c|}{ Concentration of Copper in the gills } \\
\hline $0.99 \pm 0.151$ & $1.42 \pm 0.091^{* *}$ & $1.54 \pm 0.102^{*}$ \\
\hline \multicolumn{3}{|c|}{ Concentration of Copper in the liver } \\
\hline $6.55 \pm 0.072$ & $6.84 \pm 0.044^{*}$ & $6.91 \pm 0.044^{*}$ \\
\hline \multicolumn{3}{|c|}{ Concentration of Copper in the skeletal muscles } \\
\hline $0.67 \pm 0.042$ & $0.85 \pm 0.042^{*}$ & $0.90 \pm 0.041^{*}$ \\
\hline
\end{tabular}


Activity of antioxidant enzymes in carp tissues under different concentration of Copper and Zinc in mixed fodder $(M \pm m, n=4)$

\begin{tabular}{|c|c|c|c|}
\hline Antioxidant enzymes & Control group & $\begin{array}{c}\text { The } 1^{\text {st }} \text { Experimental group } \\
\text { (1 MPL of Zinc and Copper } \\
\text { in mixed fodder) }\end{array}$ & $\begin{array}{l}\text { The } 2^{\text {nd }} \text { Experimental group } \\
\text { ( } 2 \text { MPL of Zinc and Copper } \\
\text { in mixed fodder) }\end{array}$ \\
\hline \multicolumn{4}{|c|}{ Gills } \\
\hline $\begin{array}{l}\text { Superoxide dismutase, } \\
\text { units/mg protein }\end{array}$ & $2.59 \pm 0.073$ & $2.88 \pm 0.049^{*}$ & $2.32 \pm 0.055^{*}$ \\
\hline $\begin{array}{l}\text { Glutathione peroxidase, } \\
\mu \mathrm{mol} \text { of reduced glutathione } / 100 \mathrm{mg} \text { protein } / \mathrm{min}\end{array}$ & $13.63 \pm 0.639$ & $15.77 \pm 0.491$ & $11.50 \pm 0.404^{*}$ \\
\hline $\begin{array}{l}\text { Catalase, } \\
\mu \mathrm{mol} \mathrm{H}_{2} \mathrm{O}_{2} \text { metabolized } / \mathrm{min} / \mathrm{mg} \text { protein }\end{array}$ & $4.72 \pm 0.061$ & $4.49 \pm 0.044^{*}$ & $5.06 \pm 0.087 *$ \\
\hline \multicolumn{4}{|c|}{ Liver } \\
\hline $\begin{array}{l}\text { Superoxide dismutase, } \\
\text { units/mg protein }\end{array}$ & $2.64 \pm 0.072$ & $2.92 \pm 0.047^{*}$ & $2.34 \pm 0.050^{*}$ \\
\hline $\begin{array}{l}\text { Glutathione peroxidase, } \\
\mu \mathrm{mol} \text { of reduced glutathione } / 100 \mathrm{mg} \text { protein } / \mathrm{min}\end{array}$ & $19.35 \pm 0.438$ & $21.99 \pm 0.308^{* *}$ & $18.01 \pm 0.172 *$ \\
\hline $\begin{array}{l}\text { Catalase, } \\
\mu \mathrm{mol} \mathrm{H}_{2} \mathrm{O}_{2} \text { metabolized } / \mathrm{min} / \mathrm{mg} \text { protein }\end{array}$ & $4.95 \pm 0.072$ & $4.66 \pm 0.075^{*}$ & $5.25 \pm 0.082 *$ \\
\hline \multicolumn{4}{|c|}{ Skeletal muscles } \\
\hline $\begin{array}{l}\text { Superoxide dismutase, } \\
\text { units } / \mathrm{mg} \text { protein }\end{array}$ & $2.15 \pm 0.075$ & $2.43 \pm 0.043 *$ & $1.89 \pm 0.046^{*}$ \\
\hline $\begin{array}{l}\text { Glutathione peroxidase, } \\
\mu \mathrm{mol} \text { of reduced glutathione } / 100 \mathrm{mg} \text { protein } / \mathrm{min}\end{array}$ & $13.25 \pm 0.093$ & $13.64 \pm 0.078 *$ & $12.88 \pm 0.069 *$ \\
\hline $\begin{array}{l}\text { Catalase, } \\
\mu \mathrm{mol} \mathrm{H}_{2} \mathrm{O}_{2} \text { metabolized } / \mathrm{min} / \mathrm{mg} \text { protein }\end{array}$ & $4.52 \pm 0.052$ & $4.32 \pm 0.038^{*}$ & $4.75 \pm 0.055^{*}$ \\
\hline
\end{tabular}

of main antioxidant enzymes in them (Table 2). In particular, at 1 MPL of Copper and Zinc in the mixed fodder, the activity of superoxide dismutase and catalase increased in gills, while in the liver and skeletal muscles, increase of the activity of superoxide dismutase, glutathione peroxidase and catalase was observed $(\mathrm{P}<0.05-0.01)$. Mentioned results suggested about activation of the activity of antioxidant enzymes at 1 MPL of Copper and Zinc in diet.

Table 2 presents that at 2 MPL of Copper and Zinc in the mixed fodder the activity of superoxide dismutase and glutathione peroxidase is decreased in carp gills, liver and skeletal muscles, while the activity of catalase in mentioned tissues is increased $(\mathrm{P}<0.05)$. Apparently, relatively high concentrations of Copper and Zinc in diet lead to inhibition of the activity of the main antioxidant enzymes.

The observed changes of the antioxidant enzymes activity led to change of the content of primary and secondary lipid peroxidation products (lipid hydroperoxides, conjugated dienes and malondialdehyde) in the gills, liver and skeletal muscles. In particular, at 1 MPL of Copper and Zinc in mixed fodder, concentration of lipid hydroperoxides, conjugated dienes and malondialdehyde in the gills is decreasing. Content of lipid hydroperoxides and malondialdehyde is decreasing in the liver and skeletal muscles $(\mathrm{P}<0.05-0.01)$ (Table 3). At 2 MPL of Copper and Zinc in diet, concentration of lipid hydroperoxides and malondialdehyde is increasing in the gills, and concentration of lipid hydroperoxides, conjugated dienes and malondialdehyde is decreasing in the liver and skeletal muscles $(\mathrm{P}<0.05)$.

Changes of the activity of main antioxidant enzymes, as well as alterations of content of Copper, Zinc and lipid peroxidation products in tissues were accompanied by changes of carp live weight in the end of the experiment (Table 4). For instance, during the experiment carps of control group increased their live weight 1.65 times, while carps of the $1^{\text {st }}$ and the $2^{\text {nd }}$ experimental groups -1.94 and 1.82 times, respectively. The results are pointed on growth inhibition in carp under high (2 MPL) doses of Copper and Zinc in diet. 
Concentration of lipid peroxidation products in carp tissues under different concentrations of Copper and Zinc in mixed fodder $(M \pm m, n=4)$

\begin{tabular}{|c|c|c|c|}
\hline Lipid peroxidation products & Control group & $\begin{array}{c}\text { The } 1^{\text {st }} \text { Experimental group } \\
\text { (1 MPL of Zinc and Copper } \\
\text { in mixed fodder) }\end{array}$ & $\begin{array}{c}\text { The } 2^{\text {nd }} \text { Experimental group } \\
\text { (2 MPL of Zinc and Copper } \\
\text { in mixed fodder) }\end{array}$ \\
\hline \multicolumn{4}{|c|}{ Gills } \\
\hline Lipid hydroperoxides, $\mathrm{E}_{480} / \mathrm{g}$ & $6.41 \pm 0.064$ & $5.86 \pm 0.098^{* *}$ & $6.78 \pm 0.066^{*}$ \\
\hline Conjugated dienes, $\mathrm{mmol} / \mathrm{kg}$ tissue & $118.07 \pm 1.964$ & $109.17 \pm 1.992^{*}$ & $124.63 \pm 1.386$ \\
\hline Malondialdehyde, $\mathrm{mmol} / \mathrm{g}$ & $5.87 \pm 0.058$ & $5.37 \pm 0.085^{* *}$ & $6.19 \pm 0.084^{*}$ \\
\hline \multicolumn{4}{|c|}{ Liver } \\
\hline Lipid hydroperoxides, $\mathrm{E}_{480} / \mathrm{g}$ & $8.39 \pm 0.098$ & $7.80 \pm 0.090^{*}$ & $8.75 \pm 0.081^{*}$ \\
\hline Conjugated dienes, $\mathrm{mmol} / \mathrm{kg}$ tissue & $116.60 \pm 1.587$ & $110.90 \pm 1.415$ & $124.50 \pm 1.790^{*}$ \\
\hline Malondialdehyde, $\mathrm{mmol} / \mathrm{g}$ & $13.05 \pm 0.098$ & $12.00 \pm 0.219 *$ & $14.99 \pm 0.575^{*}$ \\
\hline \multicolumn{4}{|c|}{ Skeletal muscles } \\
\hline Lipid hydroperoxides, $\mathrm{E}_{\mathrm{s} 0} / \mathrm{g}$ & $7.56 \pm 0.081$ & $6.89 \pm 0.098^{* *}$ & $7.95 \pm 0.072 *$ \\
\hline Conjugated dienes, $\mathrm{mmol} / \mathrm{kg}$ tissue & $110.70 \pm 1.380$ & $106.63 \pm 1.386$ & $116.83 \pm 1.241^{*}$ \\
\hline Malondialdehyde, $\mathrm{mmol} / \mathrm{g}$ & $9.71 \pm 0.098$ & $9.32 \pm 0.084 *$ & $10.13 \pm 0.064 *$ \\
\hline
\end{tabular}

Live weight of two year old common carp under different concentrations of Copper and Zinc in mixed fodder, $g(M \pm m, n=4)$

\begin{tabular}{|c|c|c|}
\hline Control group & $\begin{array}{c}\text { The } 1^{\text {st }} \text { Experimental group } \\
\text { (1 MPL of Zinc and Copper in mixed fodder) }\end{array}$ & $\begin{array}{c}\text { The } 2^{\text {nd }} \text { Experimental group } \\
(2 \mathrm{MPL} \text { of Zinc and Copper in mixed fodder })\end{array}$ \\
\hline \multicolumn{3}{|c|}{ In the beginning of the experiment } \\
\hline $332.2 \pm 1.77$ & $332.5 \pm 1.51$ & $332.3 \pm 1.92$ \\
\hline \multicolumn{3}{|c|}{ In the end of the experiment (45 days) } \\
\hline $548.0 \pm 2.94$ & $645.0 \pm 2.94^{* * *}$ & $604.8 \pm 3.53^{* * *}$ \\
\hline
\end{tabular}

\section{Conclusions}

At Copper concentration in mixed fodder equated to 1 MPL in comparison to its natural content, it accumulates in the gills in greater extent, than in the liver and skeletal muscles. Zinc (at concentration in the mixed fodder equated to 1 MPL) accumulates equally in the gills, liver and skeletal muscles $(\mathrm{P}<0.05)$. At $2 \mathrm{MPL}$ in the mixed fodder, Copper accumulates in all investigated tissues of carp in the same extent, while Zinc accumulates foremost in the gills and liver $(\mathrm{P}<0.01)$, and secondarily - in the skeletal muscles.

At 1 MPL of Copper and Zinc in the mixed fodder, the activity of superoxide dismutase and catalase was increased in gills, while in the liver and skeletal muscles increasing of the activity of superoxide dismutase, glutathione peroxidase and catalase was observed. At 2 MPL of Copper and Zinc in the mixed fodder, the activity of superoxide dismutase and glutathione peroxidase is decreased in carp gills, liver and skeletal muscles, while the activity of catalase in mentioned tissues is increased.

At 1 MPL of Copper and Zinc in mixed fodder, concentration of lipid hydroperoxides, conjugated dienes and malondialdehyde is decreased in the gills, and content of lipid hydroperoxides and malondialdehyde is decreased in the liver and skeletal muscles. At 2 MPL of Copper and Zinc in diet, concentration of lipid hydroperoxides and malondialdehyde is increased in the gills, and concentration of lipid hydroperoxides, conjugated dienes and malondialdehyde is decreased in the liver and skeletal muscles.

During the experiment (45 days) carps of control group increased their live weight 1.65 times, while carps of the $1^{\text {st }}$ and $2^{\text {nd }}$ experimental groups - 1.94 and 1.82 times, respectively.

Perspectives for further research. The presented results are the part of complex investigation, dedicated to research of Copper and Zinc 
influence at different concentrations on different metabolic pathways in common carp.

1. Jing Li J., Haixin Yu, Yaning Luan. MetaAnalysis of the Copper, Zinc, and Cadmium Absorption Capacities of Aquatic Plants in Heavy MetalPolluted Water. Int. J. Environ. Res. Public Health, 2015, vol. 12, № 12, pp. 14958-14973.

2. Sandor Z., Csengeri I., Oncsik M. B., Alexis M. N., Zubcova E. Trace metal levels in freshwater fish, sediment and water. Environ. Sci. Pollut. Res. Int, 2001, vol. 8, № 4, pp. 265-268.

3. Štrbac S., Kašanin-Grubin M., Jovančićević B., Simonović P. Bioaccumulation of Heavy Metals and Microelements in Silver Bream (Brama brama L.), Northern Pike (Esox lucius L.), Sterlet (Acipenser ruthenus L.), and Common Carp (Cyprinus carpio L.) From Tisza River, Serbia. J. Toxicol. Environ. Health A, 2015, vol. 78, № 11, pp. 663-665.

4. Clearwater S. J., Farag A. M., Meyer J. S. Bioavailability and toxicity of dietborne Copper and Zinc to fish. Comp. Biochem. Physiol. C. Toxicol. Pharmacol, 2002, 132, vol. 3, pp. 269-313.

5. Rajamanickam V., Muthuswamy N. Effect of heavy metals induced toxicity on metabolic biomarkers in common carp (Cyprinus Carpio L.). Mj. Int. J. Sci. Tech., 2008, vol. 12, № 01, pp. 192-200.

6. Yanovych N. E., Yanovych D. O. Role of trace elements in pond fishes vital functions. Science herald of LNUVM and BT named after S. Z. Gzhytsky., 2014, vol. 16, no. 2, pp. 345-372. (in Ukrainian)

7. Huang Y. S., Cunnane S. C., Horrobin D. F., Davignon J. Most biological effects of Zinc deficiency corrected by gamma-linolenic acid (18:3 omega 6 ) but not by linoleic acid (18:2 omega 6). Atherosclerosis, 1982, 41, pp. 193-207.
8. Reed S., Xia Qin, Ran-Ressler R., Brenna J.-T., Glahn R. P., Tako E. Dietary Zinc deficiency affects blood linoleic acid: dihomo- $\gamma$-linolenic acid (LA:DGLA) ratio; a sensitive physiological marker of Zinc status in vivo (Gallus gallus). Nutrients, 2014, vol. 6, № 3, pp. 1164-1180.

9. Wahle K. W. J., Davies N. T. Effect of dietary Copper deficiency in the rat on fatty acid composition of adipose tissue and desaturase activity of liver microsomes. British Journal of Nutrition, 1975, vol. 34, pp. 105-112.

10. Lewis R. J., Sr. Hawley's condensed chemical dictionary. $15^{\text {th }}$ ed. New York, Hoboken, Wiley, 2007, 1379 p.

11. Kostyuk V. A., Potapovuch A. I., Kovaleva G. I. Simple and sensible method of superoxide dismutase activity determination, based on reaction of cvercetin oxidation. Questions of medical chemistry, 1990, vol. 2, pp. 88-91. (in Russian)

12. Moin V. M. Simple and specific method of glutathione peroxidase activity determination in erythrocytes. Laboratory work, 1986, vol. 12, pp. 724-727. (in Russian)

13. Korolyuk M. A., Ivanova L. I., Mayorova I. G. Method of catalase activity determination. Laboratory work, 1988, vol. 1, pp. 16-18. (in Russian)

14. Price W. J. Analytical Atomic Absorption Spectrometry. Heyden and Son Ltd., London, 1972, 239 p.

15. Myronchik V. V. Technique of determination of lipid hydroperoxides in biological tissues. Patent USSR no. 1084681, 1984. (in Russian)

16. Stalnaya I. D. Determination of conjugated dienes. In: Contemporary methods in biochemistry, Orechovich V. N., ed. Moscow, Medicine, 1977, pp. 6363. (in Russian)

17. Korobeynikova S. N. Modification of definition of lipid peroxidation products in reaction with thiobarbituric acid. Laboratory work, 1989, no. 7, pp. 8-9. (in Russian) 